\title{
Peter Cooke, Gustave Moreau et les arts jumeaux, Peinture et littérature au XIX ${ }^{\mathrm{e}}$ siècle
}

\section{Ida Merello}

\section{(2) OpenEdition}

12 Journals

\section{Edizione digitale}

URL: http://journals.openedition.org/studifrancesi/35046

DOI: 10.4000/studifrancesi.35046

ISSN: 2421-5856

\section{Editore}

Rosenberg \& Sellier

\section{Edizione cartacea}

Data di pubblicazione: 1 novembre 2005

Paginazione: 441

ISSN: 0039-2944

\section{Notizia bibliografica digitale}

Ida Merello, «Peter Cooke, Gustave Moreau et les arts jumeaux, Peinture et littérature au XIX siècle», Studi Francesi [Online], 146 (XLIX | II) | 2005, online dal 30 novembre 2015, consultato il 19 avril 2021. URL: http://journals.openedition.org/studifrancesi/35046; DOI: https://doi.org/10.4000/studifrancesi. 35046

Questo documento è stato generato automaticamente il 19 avril 2021.

\section{(c) (1)}

Studi Francesi è distribuita con Licenza Creative Commons Attribuzione - Non commerciale - Non opere derivate 4.0 Internazionale. 


\title{
Peter Cooke, Gustave Moreau et les arts jumeaux, Peinture et littérature au XIX ${ }^{\mathrm{e}}$ siècle
}

\author{
Ida Merello
}

\section{NOTIZIA}

PETER COOKE, Gustave Moreau et les arts jumeaux, Peinture et littérature au XIX ${ }^{e}$ siècle, «Le Romantisme at après en France», vol. 7, Oxford etc, Lang 2003, pp. 276.

1 Questa nuova collezione, curata da Alan Raitt, raccoglie studi critici di ambiente inglese e irlandese riguardanti la letteratura francese compresa tra la fine del Settcento e gli inizi del Novecento. Il settimo volume viene a coprire una lacuna importante della critica letteraria, vale a dire un'analisi approfondita della poetica di Gustave Moreau, in funzione di una riflessione sui rapporti tra arte e letteratura. L'autore ricorda come il pittore fosse stato misconosciuto e malinteso sia da vivo - quando gli veniva rimproverato ai salons un eccesso di dettaglie di letterarietà - sia poco dopo la morte, quando contribuirono alla sua lettura di pittore/poeta anche le didascalie di Schuré a fianco ai suoi quadri, che ne facevano una sorta di freddo interprete dell'idea pura. Fu André Breton a ribaltare completamente il giudizio sul pittore, che cominciò a uscire dall'ombra negli anni Sessanta per distinguersi dall'arte accademica.

2 Dopo l'introduzione sulla fortuna storica dell'artista, l'autore passa all'analisi dell'opera, individuando la sua caratteristica fondamentale in una volontà di fusione eclettica della storia in funzione di un'evocazione simbolica, accompagnata da una sperimentazione tecnica sempre più raffinata. In seguito vengono prese in esame le trasposizioni che i letterati fecero dell'opera di Moreau e gli scritti teorici del pittore. Buon apparato bibliografico. 